\title{
THE EFFECT IN VITRO OF PROSTAGLANDINS WITH OXYTOCIN ON THE MILK-EJECTION ACTIVITY OF LACTATING SOW MAMMARY TISSUE
}

\author{
W. S. MaDOWELL, E. C. MATHER* AND C. E. MARTIN \\ University of Missouri, College of Veterinary Medicine, \\ Columbia, Missouri 65201, U.S.A.
}

(Received 3rd April 1974)

A study by Turker \& Kiran (1969) revealed that single retrograde intraarterial (i.a.) injections of prostaglandin $\mathrm{E}_{1}\left(\mathrm{PGE}_{1}\right)$ did not produce a change in milk-ejection pressure in the lactating rabbit, but could inhibit the milk-ejection response to oxytocin. The minimal dose range of $\mathrm{PGE}_{1}$ required to produce an inhibition of milk-ejection pressure by oxytocin was $0 \cdot 1$ to $1 \mu \mathrm{g} \mathrm{PGE}_{1}$ i.a.

Halder, Maiweg \& Grosvenor (1970) showed that PGE $_{1}$ could abolish the milk-ejection activity of oxytocin in the rat.

A study by McNeilly \& Fox (1971) indicated that $\mathrm{PGE}_{1}, \mathrm{PGE}_{2}, \mathrm{PGF}_{1 \alpha}$ and $\mathrm{PGF}_{2 a}$, all possessed inherent milk-ejection activity in the guinea-pig. They found that in no case did the i.a. injection of any of these four prostaglandins in amounts up to $30 \mu \mathrm{g}$ cause any decrease in, or inhibition of, the milk-ejection activity of oxytocin in the guinea-pig.

In connection with the agalactia syndrome in swine, the present study was undertaken to determine if any of the prostaglandins showed an inhibitory effect on oxytocin activity, or could be used to treat those cases of milk-ejection failure that would not respond to oxytocin therapy.

The in-vitro method described by Van Dongen \& Hays (1966) and adapted by Parkash \& Anderson (1972) for biological assay of oxytocin was adapted to lactating sow mammary tissue.

Mixed breed sows of 150 to $250 \mathrm{~kg}$ body weight with a first, second or third litter of approximately 1 week of age were procured from local swine producers. The sows were maintained in free stalls and were fed the standard University farrowing ration containing $15 \%$ protein. The sows each had from six to twelve piglets nursing at the time of purchase and throughout the experiment. Only one piglet died during the experiment.

On the day of surgery, the piglets were withheld for approximately $6 \mathrm{hr}$ and the sows were maintained without feed but with access to water.

Surgery was performed under sodium thiamylal anaesthesia injected into the ear vein or the vena cava. Tissue samples were obtained on three to four occasions, at weekly intervals, up to the 5 th week of lactation. Mammary tissue samples were obtained from one gland only and were immediately placed in Tyrode's solution.

* Present address: University of Minnesota, College of Veterinary Medicine, Saint Paul, Minnesota, U.S.A. 
The samples were divided by very sharp artery scissors into pieces approximately $2 \mathrm{~mm}^{3}$, and were maintained in Tyrode's solution until they were added to the test solutions of oxytocin or prostaglandin.

Serial dilutions of Armour's oxytocin $(20 \mathrm{U} / \mathrm{ml})$ were prepared with Tyrode's solution to produce final concentrations of $1 \times 10^{-1}, 1 \times 10^{-2}, 1 \times 10^{-3}$, $1 \times 10^{-4}$ and $1 \times 10^{-5} \mathrm{U} / 0 \cdot 1 \mathrm{ml}$.

Prostaglandins $\mathrm{PGF}_{2 \alpha}, \mathrm{PGF}_{1 \alpha}, \mathrm{PGE}_{2}, \mathrm{PGE}_{1}, \mathrm{PGA}_{1}$ and $\mathrm{PGB}_{1}$ were obtained from Upjohn Co., Kalamazoo, Michigan.

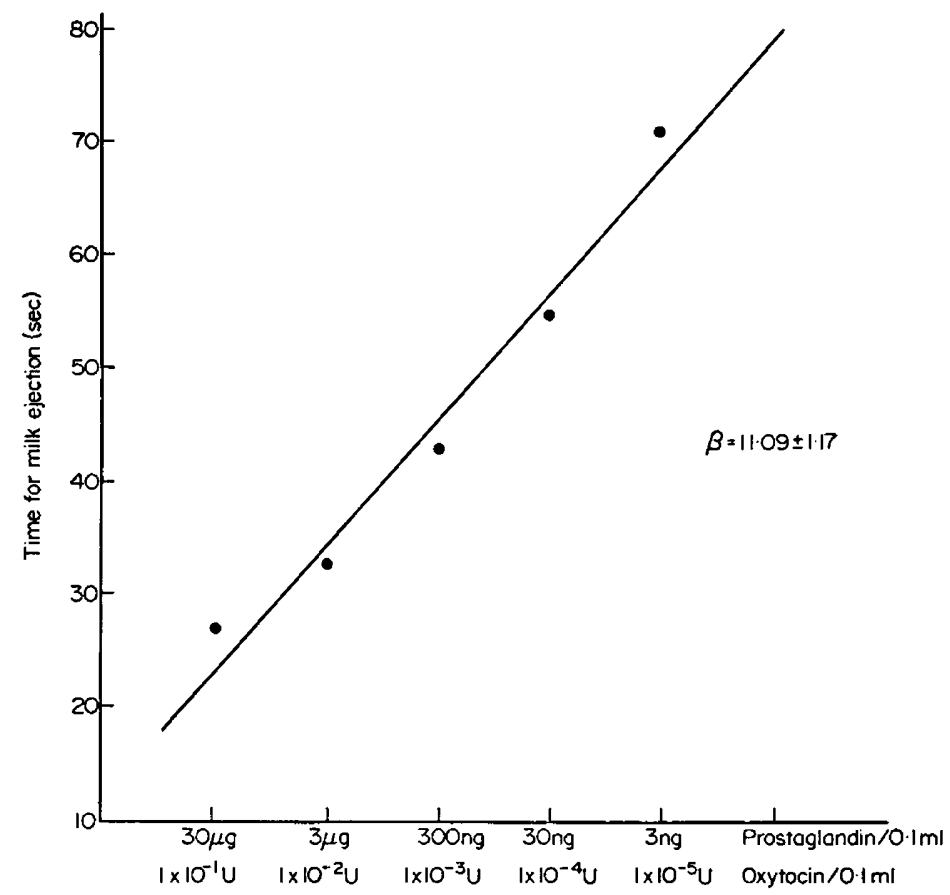

TEXT-FIG. 1. The regression of time for milk ejection to occur in lactating sow mammary tissue in vitro on oxytocin concentration. $\beta$ is the regression coefficient. Twenty-four trials with six sows were involved.

Each of the prostaglandins was first dissolved in $95 \%$ ethanol, then diluted with $0.02 \% \mathrm{Na}_{2} \mathrm{CO}_{3}$ in $0.9 \% \mathrm{NaCl}$ solution. Tenfold serial dilutions were then made by further dilution with Tyrode's solution to reach a final concentration of $30 \mu \mathrm{g}, 3 \mu \mathrm{g}, 300 \mathrm{ng}, 30 \mathrm{ng}$ and $3 \mathrm{ng}$ per $0.1 \mathrm{ml}$ of solution.

Aliquots $(0.1 \mathrm{ml})$ containing the appropriate solution of Tyrode's, oxytocin, prostaglandin, or oxytocin plus prostaglandin were placed in a $5-\mathrm{ml}$ beaker. To this solution, one cube of mammary tissue was added and immediately timed for milk ejection by a stop-watch. Three observations were made for each dilution with the aid of $a \times 7$ dissecting lens.

Sow mammary tissue response is much less sensitive to oxytocin than rat mammary tissue. The original attempts to follow the $1 \times 10^{-1} \mathrm{U}, 1 \times 10^{-3} \mathrm{U}$, $1 \times 10^{-5} \mathrm{U}, 1 \times 10^{-7} \mathrm{U}$ and $1 \times 10^{-9} \mathrm{U}$ dilutions described by Van Dongen \& Hays (1966) and Parkash \& Anderson (1972) had to be abandoned since sow 
mammary tissue would not respond to oxytocin concentrations less than $1 \times 10^{-5} \mathrm{U} / 0.1 \mathrm{ml}$. At $1 \times 10^{-1} \mathrm{U}, 1 \times 10^{-2} \mathrm{U}, 1 \times 10^{-3} \mathrm{U}, 1 \times 10^{-4} \mathrm{U}$ and $1 \times 10^{-5} \mathrm{U} / 0.1 \mathrm{ml}$, however, a dose-response curve (Text-fig. 1) could be established by the method of least squares analysis (Snedecor \& Cochran, 1967).

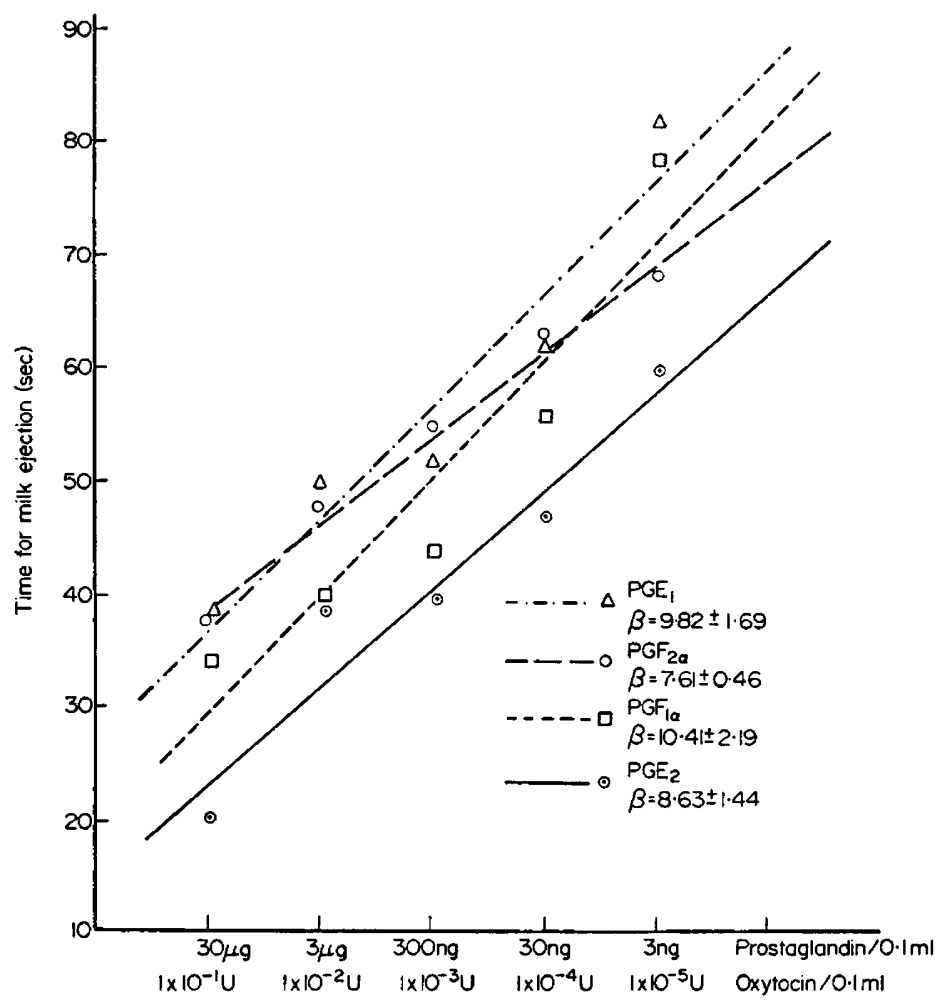

TEXT-PIG. 2. The regression of time for milk ejection to occur in lactating sow mammary tissue in vitro on $\mathrm{PGE}_{1}, \mathrm{PGE}_{2}, \mathrm{PGF}_{1 \alpha}$ and $\mathrm{PGF}_{2 \alpha}$ concentration. $\beta$ is the regression coefficient. Four trials with four sows were involved for each prostaglandin.

The dose-response curve for the 30- $\mu$ g, 3- $\mu \mathrm{g}, 300-\mathrm{ng}, 30-\mathrm{ng}$ and 3-ng level of each prostaglandin was established (Text-fig. 2). By the method of least squares analysis $\mathrm{PGF}_{1 \alpha}, \mathrm{PGF}_{2 \alpha}, \mathrm{PGE}_{1}$ and $\mathrm{PGE}_{2}$ followed a linear regression pattern that was significant $(P<0 \cdot 05)$. Prostaglandins $P_{G A_{1}}$ and $P G_{1}$ possessed some inherent oxytocic activity, but failed to establish a significant pattern of regression.

When the response for each set of sows was adjusted to remove variation among groups, the prostaglandins with only the 13-trans double bond $\left(\mathrm{PGE}_{1}\right.$, $\mathrm{PGF}_{1 a}$ ) had regression slopes that most closely paralleled that of oxytocin. The prostaglandins with the 5-cis, 13-trans double bonds $\left(\mathrm{PGE}_{2}, \mathrm{PGF}_{2 \alpha}\right)$ had somewhat more additive activity with oxytocin than either $\mathrm{PGE}_{1}$ or $\mathrm{PGF}_{1 \alpha}$. When compared to oxytocin, the milk-ejection activity of the prostaglandins was generally less than $3.0 \%$ of the activity of oxytocin on a wt/wt basis.

The physiological range of oxytocin activity in lactating sows measured by 
rat mammary cube bioassay was found to vary from 5 to $132 \mu \mathrm{U} / \mathrm{ml}$ plasma by Folley \& Knaggs (1966).

Byerly, Hoefling, Meyer \& Simon (1971) found mean levels of $46 \mu \mathrm{U} / \mathrm{ml}$ oxytocin at 1 min following stimulation, and levels of $5.5 \mu \mathrm{U}$ and $3.4 \mu \mathrm{U} / \mathrm{mI}$ respectively at 2- and 3-min intervals following stimulation in sows with short nursing periods.

In our system, this would equate to the oxytocin response falling between $1 \times 10^{-2}$ and $1 \times 10^{-4} \mathrm{U} / 0.1 \mathrm{ml}$.

Measured physiological levels of prostaglandins in the sow are not known to have been recorded, but Diehl (1973) found that infusion of $200 \mu \mathrm{gGF}_{2 \alpha}$ per hour on Day 107, 108, or 109 of pregnancy in gilts resulted in the appearance of mammary fluid in $5.9 \pm 1.9 \mathrm{hr}$ after the start of infusion. Intramuscular injections of $5 \mathrm{mg} \mathrm{PGF}_{2 \alpha}$ and $2.5 \mathrm{mg} \mathrm{PGF}_{2 \alpha}$ gave similar results.

A 182-kg sow has approximately $4 \mathrm{ml}$ plasma per $100 \mathrm{~g}$ body weight (Calhoun \& Smith, 1958). Therefore, the maximum amount of circulating PGF $_{2 \alpha}$ in Diehl's study would be unlikely to exceed $16 \cdot 2 \mathrm{ng} / 0 \cdot 1 \mathrm{ml}$.

Extrapolating from these data, of the five levels of prostaglandins used in this study, only the $3 \mathrm{ng} / 0.1 \mathrm{ml}$ level is likely to be a physiological level. At this level, the only significant effect of any of the prostaglandins studied was an additive effect to oxytocin.

Our results agree with those of McNeilly \& Fox (1971) for the guinea-pig in that none of the prostaglandins studied were inhibitory to oxytocin in amounts up to $30 \mu \mathrm{g}$ per $0.1 \mathrm{ml}$.

The prostaglandins studied seem unlikely to be inhibitory to oxytocin in the lactating sow, or to be superior to oxytocin given alone as a treatment for lactation failure. Further studies, carried out in vivo, would be necessary to support this conclusion.

Sincere appreciation is extended to Dr J. Lauderdale and Dr J. E. Pike and the Upjohn Co., Kalamazoo, Michigan, for the generous gift of the prostaglandins used in this study. Further appreciation is extended to Dr Ralph Anderson of the Department of Dairy Science and to Dr Gary Krause of the Department of Statistics, University of Missouri for their technical assistance and advice. This study was supported by the U.S.D.A. grant 9014-2511 for the study of lactation failure in the sow.

\section{REFERENGES}

Byerly, C. S., Hoefling, D. G., Meyer, R. C. \& Simon, J. (1971) Mastitis-Metritis-Agalactia Syndrome in Sows. Illinois Agricultural Exp. Stn. Report to the NGR-64 Technical Committee, March 1971, Ames, Iowa.

CAlmoun, M. L. \& Smrth, E. M. (1958) Hematology and hematopoietic organs. In Diseases of Swine, p. 37. Ed. H. W. Dunne. Iowa State Press, Ames, Iowa, U.S.A.

DIEHL, J. R. (1973) Luteolytic effects of prostaglandin $F_{2 a}$ in swine. Ph.D. thesis, University of Missouri, Columbia.

Folley, S. J. \& KNAGGs, G. S. (1966) Milk-ejection activity (oxytocin) in the external jugular vein blood of the cow, goat, and sow, in relation to the stimulus of milking or suckling. F. Endocr. 34, 197.

Halder, J., Matweg, H. \& Grosvenor, C.E. (1970) Inhibition by prostaglandin of oxytocin-induced contraction of breast myoepithelium. Proc. 52nd Meeting, Endocr. Soc., St. Louis, p. 130, Abstr. 
MaNeilly, A. S. \& Fox, C. A. (1971) The effect of prostaglandins on the guinea-pig mammary gland. 7. Endocr. 51, 603.

Parkash, V. \& Anderson, R. R. (1972) Pituitary and blood plasma oxytocic activity and oxytocin disappearance rates in cattle. F. Dairy Sci. 55, 75.

Snedecor, G. W. \& Cochran, W. G. (1967) Statistical Methods, 6th edn. Iowa State Press, Ames, Iowa.

TURKER, R. K. \& KIRAN, B. K. (1969) Interaction of prostaglandin E with oxytocin on mammary gland of the lactating rabbit. Eur. F. Pharmac. 8, 377.

Van Dongen, G. G. \& Hays, R. L. (1966) A sensitive in vitro assay for oxytocin. Endocrinology, 78, 1. 